\title{
Innovation of education for the development of key competencies of university graduates
}

DOI 10.1515/otmcj-2016-0019

Received September 05, 2016; accepted May 10, 2017

\begin{abstract}
Competency-based education is a new trend in the process of teaching to support and develop the competencies of graduates. This challenge of the European Union aimed at changes in learning processes contributes to improvement in the educational qualifications of the population. Recently, in Europe and Slovakia, several research studies aimed at key competencies of graduates have been conducted. This paper provides the results of the study aimed at identification of key competencies of graduates of the study program Construction Technology and Management. A proposal for innovations in learning forms is presented as an output of the national project "Universities as Engines of Knowledge Society Development". The innovations will influence the development of profession-specific and transferable competencies of graduates of the afore-mentioned study program at the Faculty of Civil Engineering in Technical University of Košice, Slovakia.
\end{abstract}

Keywords: competencies, key competencies, knowledge, skills, innovations, higher education, university graduate

\section{Introduction}

Systematic reflections, analyses, and evaluations of education, as well as efforts to enhance and innovate the educational process, are inevitable to improve the development of university graduates' competencies.

Continuous improvement and innovations in academic education, i.e., various innovations in contents, methods, forms, and organization of education, should support knowledge, skills, and competencies of academic graduates. The methodology of the Plan-Do-Check-Act

*Corresponding author: Zuzana Struková, Faculty of Civil Engineering, Technical University of Košice, Vysokoškolská 4, 04200 Košice,

Slovakia, Email: zuzana.strukova@tuke.sk
(PDCA) approach describes innovations in any process in general. The cycle includes the following four steps:

1. Plan - plan, set objectives, and determine intention of improving;

2. Do - realize, implement, execute, and carry out the intention;

3. Check - check, observe, verify, measure the level of achieving the objectives, compare, and evaluate the results achieved;

4. Act - make corrections and changes if results do not reflect the intentions planned, make your choice and receive improvement actions, and create a new plan.

The PDCA process is precious because of its simplicity and stress on continuity. Continuity is ensured by systematic repetition of the cycle. An innovation will become a common part of education if defining and implementing it in the education process brings about better outcomes (Blaško 2016).

The European Union has long been trying to predict the changes in necessary knowledge and skills of the future population and to harmonize existing competencies of graduates with the competencies demanded by the labor market (Kozlovská et al. 2015; Mesároš et al. 2014).

In the years 2013-2015, the Slovak Republic was engaged in research on key competencies necessary for the success of university graduates in the labor market. The research on the national project "Universities as Engines of Knowledge Society Development” included several stages with the following partial goals:

- Analysis of macroeconomic premises and trends prognosis of development of university graduates' labor market;

- Attribution of weights to industries in terms of their international competitiveness and added value in the economy (identification of high-relevance sectors);

- Identification of occupations and educational specializations linked to the high-relevance sectors;

- Interconnection of educational specialization with real study programs;

- Assessment of study programs in a multifactor model, with the concept of graduates' employability in the labor market in relevant sectors as the essence; 
- Creation of a group of study programs with high prospects, recommended for the next level of cooperation in the National Project (students in practice, university departments equipment, proposals for innovations of study program in terms of strengthening the link of curricula with practice).

A team of people from the Faculty of Civil Engineering at the Institute of Construction Technology and Management of the Technical University of Košice has been engaged in the project in its fifth stage (the year 2015). The stage was aimed at "Assessment of effectiveness of university study programs". The results of this part of the project were presented and summarized in "Recommendations to optimize the content and forms of study to needs of practice for the study program Construction Technology and Management - First and second levels" (PricewaterhouseCoopers Slovensko, s.r.o. - Centire s.r.o. 2015).

The graduates of Construction Technology and Management study program are, from the labor market side, expected to have profession-specific competencies inevitable for the solution of tasks related to construction preparation and completion (Kozlovská et al. 2010), construction cost and quality (Tažiková and Kozlovská 2013), as well as environmental protection in the life cycle of any construction (Kozlovská and Spišáková 2013).

\section{Key competencies of graduates' education}

The key competencies are determined by the set of knowledge, skills, and attitudes needed by everyone for their personal implementation and development, to participate in society, and find successful employment.

While the European Qualification Framework (European Communities 2008) specifies the learning outcomes in three categories (knowledge, skills, and competence), according to the national system of professions in the Slovak Republic, competencies are divided into general competence, professional knowledge, and professional skills. According to other commonly used approaches, the competencies are transferable and nontransferable, i.e., profession-specific (job-specific hard skills). A person may conveniently use transferable competencies in various professions, whereas nontransferable competencies are tied to a particular job or profession (e.g., estimating clerk, site manager, and so on). The transferable competencies are subdivided into "transferable soft competencies", verified for instance within 360-degree feedback, and "transferable hard competencies" (generic hard), verifiable by tests or examinations.

Recently, several international organizations and some countries, including the European Union Member States, have attempted to define the key competencies of graduates. For example, the Definition and Selection of Competencies Project of the Organisation for Economic Co-operation and Development (OECD) (http://www.oecd. org/pisa/35070367.pdf 2005) has classified the key competencies into three broad categories:

1. Individuals should be able to use a wide range of instruments for effective interaction with the environment: cognitive (knowledge and skills), material (e.g., digital technologies), and sociocultural tools (e.g., language). They must sufficiently understand such instruments in order to adapt them for their own purposes and to use instruments in an interactive way.

2. Individuals should be able to work with others in an increasingly interdependent world. Since they will encounter people from a range of backgrounds, it is essential that they are able to interact in heterogeneous groups.

3. Individuals should be able to take responsibility for managing their own lives, situate their lives in the broader social context, and act autonomously.

The Careers after Higher Education: a European Research Study (CHEERS) from 1995, examining the employment of graduates in the labor market, involved 12 European countries (Germany, Finland, France, Great Britain, Italy, Netherlands, Norway, Austria, Sweden, Spain, Czech, and Japan; Bitterová and Hašková 2014). Similarly, the project REFLEX (The Flexible Professional in the Knowledge Society 2004 and 2007), was executed in 16 European countries (Austria, Belgium, Flanders, Czech Republic, Estonia, Finland, France, Germany, Italy, Netherlands, Norway, Portugal, Spain, Sweden, Switzerland, and the United Kingdom) and Japan. In the following years, its international and national replications took place. For example, the project HEGESCO (Higher Education as a Generator of Strategic Competences) was executed in 2009 in Slovenia, Turkey, Latvia, Poland, and Hungary; the projects PROFLEX (2009), REFLEX (2010), and the Czech Republic project REFLEX (2013) were executed. All the projects were based on the same methodology developed by the net REFLEX. A representative sample of graduates was involved in the questionnaire survey. The respondents graduated from universities no longer than 5 years before survey execution. A data set REFLEX/HEGESCO 
correlates the learning process and the positions of graduates in the labor market. Dozens of other studies (EUROGRADUATE Consortium 2016) have been based on the data sets CHEERS, REFLEX, and HEGESCO. These projects have never involved the Slovak Republic. Slovakia still does not have any national system to monitor graduates' application in practice and to harmonize achieved competence with demands of the practice. According to the Economic Policy Institute (EPI, a nonprofit organization) analysis in 2011 (Kleštincová 2011), many data sets under the auspices of several institutions characterize the output of education from a quantitative point of view, but the data do not offer any preview of the actual usability, in practice, of the achieved knowledge and skills to improve the employability of graduates.

Hrmo and Turek (2013) presented a paper on the systems and structure of key competencies in European Member States and OECD States and an overview of key competencies proposed by some international organizations and some countries such as the US, England and Wales, Canada, Germany, Switzerland, Czech Republic (Ministry of Education, Youth and Sports of Czech Republic [MŠMaT ČR] 2001) and Slovak Republic (MŠ SR. 2002). The authors have mentioned that valid and reliable determination of a key competencies system that must be developed and improved at all levels and types of school in Slovakia, as well as in lifelong learning, should come from wide research on finding the most essential knowledge, skills, competencies, attitudes, and value system that

- employers exact from their employees,

- employees regard as the most important for success of employment,

- citizens of the Slovak Republic regard as crucial for a contented, happy life and for effective functioning of a democratic society,

- can be used in forecasting by engaged professionals as critical for a meaningful life in the future.

\section{Methodology}

The proposal of innovations in forms of education that influence the development of key competencies of graduates of the study program Technology and Construction Management at the Faculty of Civil Engineering at the Technical University of Košice was based on the results of the national project "Universities as Engines of Knowledge Society Development”.

A profile of the required key competencies of the study program graduates was assembled at the beginning of the project. In the profile, the key competencies are divided into the following two categories:

- Profession-specific competencies and

- Transferable competencies:

○ hard transferable competencies,

○ soft transferable competencies.

The specific innovations in the learning process were proposed based on the analysis of requirements in the profile and the key competencies of Bachelor's and Master's study graduates stated by employers' representatives and teachers.

To unveil the key profession-specific competencies and soft transferable competencies of graduates of the study program Construction Technology and Management, various employers of the construction industry in Slovakia have contributed to the study through a questionnaire survey. First, a brainstorming meeting of university teachers was conducted. Nine teachers from the Faculty of Civil Engineering developed the lists of potential profession-specific and soft transferable competencies of graduates. The lists were prepared based on the characteristics of the study program for the Bachelor's and Master's degrees. To find out the key competencies, employers of the construction industry were asked, in the questionnaire survey, to rate each of the potential key competencies stated at the brainstorming meeting of teachers. Their rating was made based on their perception and long-time experiences. Overall, 105 questionnaires were sent and 48 of them were returned. Thus, the returned/sent ratio was 0.46 .

In the survey, employers were asked to rate each competence on a five-point Likert scale, ranging from one (less important competence) to five (critical competence). Ratings were made separately for Bachelor's and Master's study programs. In the case of transferable competencies, only the soft ones were analyzed through the questionnaire survey. Hard transferable competencies were determined directly by university teachers during the meeting.

Based on the mean of all the competencies, the profile of key competencies was determined. The group of teachers from the Faculty of Civil Engineering engaged in the study decided to include the competencies with mean value $\geq 4.00$ into the profile of the key competencies.

\section{Results and discussion}

According to the System of Study Specializations in the Slovak Republic, the study program Construction Technology and Management (first level - Bachelor's study; and second level - Master's study) falls into the specialization 
"Engineering Design, Technologies, Manufacturing and Communications" (subgroup 5.2.8 Construction) and according to the International Standard Classification of Education (ISCED 2011), it falls into study specialization "Engineering, Manufacturing and Construction".

Based on the characteristics of the study program, the list of potential key profession-specific competencies for Bachelor's and Master's study programs was prepared. The list involves these competencies:

A. Have basic knowledge of building preparation and construction and of construction method organization

B. Use automated systems focused on time and cost planning of construction

C. Perform checks and controls of building product quality

D. Have knowledge of the whole spectrum of building technologies and materials

E. Promote ecologic awareness and environmental protection in building practice solutions

F. Have basic knowledge of building and business law, teamwork, and coordination with specialists from other professions

G. Use information technology (IT) and software for building preparation, execution, and designing

H. Have basic knowledge of designing, structural solutions, and technical equipment of buildings

I. Manage investment in construction projects

J. Have knowledge of occupational health and safety

K. Have basic theoretical knowledge of natural disciplines

L. Work on construction projects involving identification of problem, analysis and implementation of extensive solutions related to design of buildings, and execution in interaction with particular economic, environmental, and social aspects

M. Have basic knowledge of demands on good-quality, safe, and environmentally acceptable preparation and construction of buildings

N. Solve practical problems of construction practice using theoretical knowledge

O. Have knowledge of construction project economy

P. Have basic knowledge of calculation methods for architectural and civil engineering buildings

Q. Have knowledge of logistics, as well as transport of machines and material

R. Have ecological sense and have knowledge of environmental protection

S. Manage and control technological procedures of construction

T. Have knowledge of pricing

U. Carry out activities relating to construction preparation and management of diverse types of structural and civil engineering buildings (management of organizational and technological problems)

V. Have basic knowledge of designing and solutions for traffic and water structures

W. Analyze building design documentation in response to source assessment

$\mathrm{X}$. Plan and manage, coordinate, and control projects of structural and civil engineering buildings

Y. Use new practices and technologies

Z. Use knowledge related to building renovation technology and the specifics of renovation preparation and execution

AA. Use economic information systems and integrated systems of construction project management, including complex controlling of building production management

The results of the rating of the potential key professionspecific competencies for the study program Construction Technology and Management (Bachelor's study), as rated by employers, are presented in Tab. 1 .

From the results of the rating (Tab. 1), it is evident that the profile of key profession-specific competencies for Bachelor's study involves the following competencies with mean value $\geq 4.00$ : carry out activities relating to construction preparation and management of diverse types of structural and civil engineering buildings; manage and control technological procedures of construction; use IT and software for building preparation, execution, and designing; solve practical problems of construction practice using theoretical knowledge; perform checks and controls of building product quality; and analyze building design documentation in response to source assessment.

The results of the rating made by employers of the potential key profession-specific competencies for the study program Construction Technology and Management (Master's study) are presented in Tab. 2.

From the results of the rating (Tab. 2), it is evident that the profile of key profession-specific competencies for Master's study involves the following competencies with mean value $\geq 4.00$ : plan and manage, coordinate, and control projects of structural and civil engineering buildings; manage investment construction projects; use automated systems focused on time and cost planning of construction; work on construction projects involving identification of problem, analysis, and implementation of extensive solutions related to building design, and execution in interaction with particular economic, environmental, and social aspects; use knowledge related to building renovation technology and the specifics of renovation preparation and execution; use economic information systems and integrated systems of construction 
Tab. 1: The rating of potential key profession-specific competencies of graduates of the study program Construction Technology and Management - first level (Bachelor's degree)

\begin{tabular}{|c|c|c|c|c|c|c|c|}
\hline \multicolumn{2}{|c|}{ Competence } & \multicolumn{6}{|c|}{ Number of respondents } \\
\hline Sign & Designation & 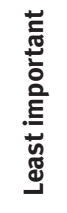 & 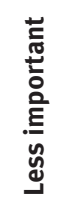 & 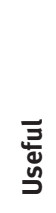 & 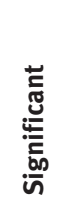 & 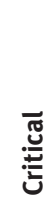 & $\begin{array}{l}\text { ॠ } \\
\sum \\
\Sigma\end{array}$ \\
\hline $\mathrm{U}$ & $\begin{array}{l}\text { Carry out activities relating to construction preparation and management of diverse types } \\
\text { of structural and civil engineering buildings }\end{array}$ & 0 & 0 & 0 & 5 & 43 & 4.90 \\
\hline S & Manage and control technological procedures of construction & 0 & 0 & 2 & 7 & 39 & 4.77 \\
\hline G & Use IT and software for building preparation, execution, and designing & 0 & 0 & 1 & 11 & 36 & 4.73 \\
\hline $\mathrm{N}$ & Solve practical problems of construction practice using theoretical knowledge & 2 & 0 & 6 & 14 & 26 & 4.29 \\
\hline $\mathrm{C}$ & Perform checks and controls of building product quality & 0 & 1 & 8 & 16 & 23 & 4.27 \\
\hline W & Analyze building design documentation in response to source assessment & 0 & 0 & 14 & 10 & 24 & 4.21 \\
\hline J & Have knowledge of occupational health and safety & 1 & 5 & 10 & 12 & 20 & 3.94 \\
\hline K & Have basic theoretical knowledge of natural disciplines & 1 & 6 & 9 & 13 & 19 & 3.90 \\
\hline $\mathrm{H}$ & $\begin{array}{l}\text { Have basic knowledge of designing, structural solutions, and technical equipment of } \\
\text { buildings }\end{array}$ & 2 & 7 & 10 & 11 & 18 & 3.75 \\
\hline $\mathrm{X}$ & $\begin{array}{l}\text { Plan and manage, coordinate, and control projects of structural and civil engineering } \\
\text { buildings }\end{array}$ & 3 & 4 & 8 & 22 & 11 & 3.71 \\
\hline M & $\begin{array}{l}\text { Have basic knowledge of demands on good-quality, safe, and environmentally acceptable } \\
\text { preparation and construction of buildings }\end{array}$ & 2 & 9 & 9 & 12 & 16 & 3.68 \\
\hline $\mathrm{T}$ & Have knowledge of pricing & 2 & 10 & 10 & 11 & 15 & 3.56 \\
\hline Y & Use new practices and technologies & 2 & 12 & 9 & 11 & 14 & 3.48 \\
\hline $\mathrm{E}$ & Promote ecologic awareness and environmental protection in building practice solutions & 4 & 8 & 12 & 10 & 14 & 3.46 \\
\hline I & Manage investment construction projects & 3 & 12 & 9 & 10 & 14 & 3.42 \\
\hline B & Use automated systems focused on time and cost planning of construction & 3 & 11 & 11 & 10 & 13 & 3.40 \\
\hline $\mathrm{P}$ & $\begin{array}{l}\text { Have basic knowledge of calculation methods for architectural and civil engineering } \\
\text { buildings }\end{array}$ & 2 & 14 & 11 & 9 & 12 & 3.31 \\
\hline $\mathrm{L}$ & $\begin{array}{l}\text { Work on construction projects involving identification of problem, analysis and implemen- } \\
\text { tation of extensive solutions related to design of buildings, and execution in interaction } \\
\text { with particular economic, environmental, and social aspects }\end{array}$ & 4 & 14 & 8 & 10 & 12 & 3.25 \\
\hline 0 & Have knowledge of construction project economy & 4 & 15 & 7 & 10 & 12 & 3.23 \\
\hline $\mathrm{R}$ & Have ecological sense and have knowledge of environmental protection & 3 & 17 & 7 & 10 & 11 & 3.19 \\
\hline D & Have knowledge of the whole spectrum of building technologies and materials & 4 & 16 & 8 & 9 & 11 & 3.15 \\
\hline AA & $\begin{array}{l}\text { Use economic information systems and integrated systems of construction project man- } \\
\text { agement, including complex controlling of building production management }\end{array}$ & 5 & 15 & 10 & 8 & 10 & 3.06 \\
\hline V & Have basic knowledge of designing and solution for traffic and water structures & 5 & 16 & 9 & 8 & 10 & 3.04 \\
\hline Z & $\begin{array}{l}\text { Use knowledge related to building renovation technology and the specifics of renovation } \\
\text { preparation and execution }\end{array}$ & 9 & 12 & 10 & 8 & 9 & 2.92 \\
\hline A & $\begin{array}{l}\text { Have basic knowledge of building preparation and construction and of construction } \\
\text { method organization }\end{array}$ & 9 & 13 & 8 & 9 & 9 & 2.92 \\
\hline$F$ & $\begin{array}{l}\text { Have basic knowledge of building and business law, teamwork, and coordination with } \\
\text { specialists from other professions }\end{array}$ & 10 & 10 & 15 & 6 & 7 & 2.79 \\
\hline Q & Have knowledge of logistics, as well as transport of machines and material & 9 & 12 & 13 & 8 & 6 & 2.79 \\
\hline
\end{tabular}

project management, including complex controlling of building production management; and promote ecologic awareness and environmental protection in building practice solutions.

The content and methods of teaching of professional subjects provide a strong theoretical and practical basis, supported by the newest techniques and technologies, for solution of engineering tasks connected with preparation and management of challenging projects of structural and traffic buildings.

The hard transferable competencies of graduates of the study program Construction Technology and Management (Master's study) defined by teachers are presented in Tab. 3.

The results of the rating of potential key soft transferable competencies, made by employers, for the study 
Tab. 2: The rating of potential key profession-specific competencies of graduates of the study program Construction Technology and Management - second level (Master's study)

\begin{tabular}{|c|c|c|c|c|c|c|c|}
\hline \multicolumn{2}{|c|}{ Competence } & \multicolumn{6}{|c|}{ Number of respondents } \\
\hline Sign & Designation & 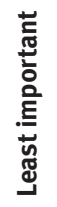 & 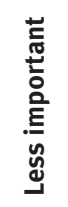 & 胥 & 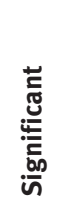 & $\stackrel{\sqrt[T]{20}}{:}$ & 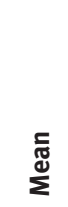 \\
\hline $\mathrm{x}$ & $\begin{array}{l}\text { Plan and manage, coordinate, and control projects of structural and civil engineering } \\
\text { buildings }\end{array}$ & 0 & 0 & 0 & 2 & 46 & 4.96 \\
\hline I & Manage investment construction projects & 0 & 0 & 0 & 3 & 45 & 4.94 \\
\hline B & Use automated systems focused on time and cost planning of construction & 0 & 0 & 1 & 2 & 45 & 4.92 \\
\hline $\mathrm{L}$ & $\begin{array}{l}\text { Work on construction projects involving identification of problem, analysis and implemen- } \\
\text { tation of extensive solutions related to building design, and execution in interaction with } \\
\text { particular economic, environmental, and social aspects }\end{array}$ & 0 & 0 & 1 & 6 & 41 & 4.83 \\
\hline Z & $\begin{array}{l}\text { Use knowledge related to building renovation technology and the specifics of renovation } \\
\text { preparation and execution }\end{array}$ & 0 & 1 & 0 & 7 & 40 & 4.79 \\
\hline AA & $\begin{array}{l}\text { Use economic information systems and integrated systems of construction project man- } \\
\text { agement, including complex controlling of building production management }\end{array}$ & 0 & 2 & 2 & 8 & 36 & 4.63 \\
\hline $\mathrm{E}$ & Promote ecologic awareness and environmental protection in building practice solutions & 0 & 3 & 5 & 10 & 30 & 4.40 \\
\hline $\mathrm{C}$ & Perform checks and controls of building product quality & 1 & 5 & 13 & 5 & 24 & 3.96 \\
\hline K & Have basic theoretical knowledge of natural disciplines & 1 & 4 & 15 & 4 & 24 & 3.96 \\
\hline $\mathrm{U}$ & $\begin{array}{l}\text { Carry out activities relating to construction preparation and management of diverse types } \\
\text { of structural and civil engineering buildings (management of organizational and techno- } \\
\text { logical problems) }\end{array}$ & 2 & 5 & 10 & 8 & 23 & 3.94 \\
\hline H & $\begin{array}{l}\text { Have basic knowledge of designing, structural solutions, and technical equipment of } \\
\text { buildings }\end{array}$ & 1 & 4 & 17 & 2 & 24 & 3.92 \\
\hline $\mathrm{T}$ & Have knowledge of pricing & 5 & 1 & 8 & 13 & 21 & 3.92 \\
\hline V & Have basic knowledge of designing and solutions for traffic and water structures & 5 & 3 & 6 & 13 & 21 & 3.88 \\
\hline $\mathrm{N}$ & Solve practical problems of construction practice using theoretical knowledge & 3 & 4 & 7 & 15 & 19 & 3.86 \\
\hline M & $\begin{array}{l}\text { Have basic knowledge of demands on good-quality, safe, and environmentally acceptable } \\
\text { preparation and construction of buildings }\end{array}$ & 2 & 5 & 8 & 16 & 17 & 3.85 \\
\hline $\mathrm{F}$ & $\begin{array}{l}\text { Have basic knowledge of building and business law, teamwork, and coordination with } \\
\text { specialists from other professions }\end{array}$ & 4 & 5 & 5 & 15 & 19 & 3.83 \\
\hline Y & Use new practices and technologies & 5 & 4 & 8 & 16 & 15 & 3.67 \\
\hline S & Manage and control technological procedures of construction & 2 & 8 & 11 & 14 & 13 & 3.58 \\
\hline W & Analyze building design documentation in response to source assessment & 5 & 6 & 9 & 14 & 14 & 3.54 \\
\hline J & Have knowledge of occupational health and safety & 4 & 7 & 11 & 12 & 14 & 3.52 \\
\hline $\mathrm{P}$ & $\begin{array}{l}\text { Have basic knowledge of calculation methods for architectural and civil engineering } \\
\text { buildings }\end{array}$ & 2 & 6 & 15 & 13 & 12 & 3.35 \\
\hline G & Use IT and software for building preparation, execution, and designing & 3 & 10 & 13 & 11 & 11 & 3.35 \\
\hline $\mathrm{R}$ & Have ecological sense and have knowledge of environmental protection & 4 & 13 & 11 & 10 & 10 & 3.19 \\
\hline D & Have knowledge of the whole spectrum of building technologies and materials & 4 & 16 & 10 & 7 & 11 & 3.10 \\
\hline 0 & Have knowledge of construction project economy & 2 & 17 & 13 & 8 & 8 & 3.06 \\
\hline A & $\begin{array}{l}\text { Have basic knowledge of building preparation and construction and of construction } \\
\text { method organization }\end{array}$ & 2 & 19 & 13 & 6 & 8 & 2.98 \\
\hline Q & Have knowledge of logistics, as well as transport of machines and material & 4 & 20 & 15 & 6 & 3 & 2.67 \\
\hline
\end{tabular}

program Construction Technology and Management (Master's study) are presented in Tab. 4.

From the results of the rating (Tab. 4), it is evident that the profile of key soft transferable competencies for the Master's study involves the following competencies with the mean value $\geq 4.00$ : ability to use professional knowledge in practice; get ambiguity under control; organization and planning, setting priorities; bargaining (negotiating) skills; independence, ability to take responsibility; ability to identify and solve problems; analytical thinking; information management; time management; ability to lead a team; leadership skills; convincing and argumentation skills; customer orientation; and self-control and stress resistance.

The team of experts dealing with innovation of learning process, which was engaged in the national project "Universities as Engines of Knowledge Society Development” in 
Tab. 3: Hard transferable competencies of graduates of the study program Construction Technology and Management (second level - Master's study) for different working positions

\section{Transferable competencies - hard}

Professional theoretical and methodological knowledge

Knowledge of English

Knowledge of German

Knowledge of French

Knowledge of another foreign language in addition to English, German, and French

Mathematical skills

ICT (Information Communication Technology) skills/e-skills

Ability to think and act economically/financial competencies

Awareness of legal and regulatory framework

Tab. 4: The rating of potential key soft transferable competencies of graduates of the study program Construction Technology and Management (second level- Master's study) for different working positions

\begin{tabular}{|c|c|c|c|c|c|c|c|}
\hline \multicolumn{2}{|c|}{ Competence } & \multicolumn{6}{|c|}{ Number of respondents } \\
\hline Sign & Designation & 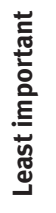 & 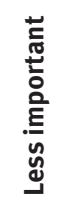 & 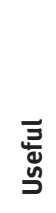 & 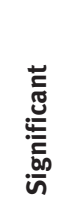 & 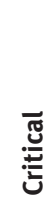 & 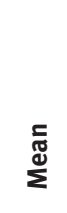 \\
\hline I & Ability to use professional knowledge in practice & 0 & 0 & 0 & 1 & 47 & 4.98 \\
\hline II & Get ambiguity under control & 0 & 0 & 1 & 1 & 46 & 4.94 \\
\hline III & Organization and planning, setting priorities & 0 & 0 & 2 & 0 & 46 & 4.92 \\
\hline IV & Bargaining (negotiating) skills & 0 & 0 & 1 & 2 & 45 & 4.92 \\
\hline V & Independence, ability to take responsibility & 0 & 1 & 0 & 3 & 44 & 4.88 \\
\hline VI & Ability to identify and solve problems & 0 & 0 & 2 & 3 & 43 & 4.85 \\
\hline VII & Analytical thinking & 0 & 0 & 4 & 2 & 42 & 4.79 \\
\hline VIII & Information management & 0 & 3 & 0 & 2 & 43 & 4.77 \\
\hline IX & Time management & 1 & 2 & 0 & 0 & 45 & 4.75 \\
\hline $\mathrm{x}$ & Ability to lead a team & 0 & 2 & 3 & 2 & 41 & 4.71 \\
\hline $\mathrm{XI}$ & Leadership skills & 0 & 4 & 0 & 3 & 41 & 4.69 \\
\hline XII & Convincing and argumentation skills & 0 & 2 & 5 & 5 & 36 & 4.56 \\
\hline XIII & Customer orientation & 0 & 4 & 4 & 7 & 33 & 4.44 \\
\hline XIV & Self-control and stress resistance & 2 & 3 & 5 & 12 & 26 & 4.19 \\
\hline $\mathrm{XV}$ & Good writing and communication skills & 4 & 5 & 6 & 7 & 26 & 3.96 \\
\hline XVI & Honorable conduct and character & 0 & 10 & 8 & 5 & 25 & 3.94 \\
\hline XVII & Assertiveness & 2 & 8 & 10 & 3 & 25 & 3.85 \\
\hline XVIII & Intellectual performance & 1 & 10 & 10 & 3 & 24 & 3.81 \\
\hline XIX & Learning on the fly & 2 & 12 & 4 & 6 & 24 & 3.79 \\
\hline $\mathrm{XX}$ & Flexibility & 3 & 6 & 12 & 7 & 20 & 3.73 \\
\hline XXI & Orientation to rules, quality, and accuracy & 3 & 8 & 10 & 5 & 22 & 3.73 \\
\hline XXII & Active reception & 5 & 10 & 3 & 7 & 23 & 3.69 \\
\hline XXIII & Self-knowledge & 3 & 12 & 4 & 8 & 21 & 3.67 \\
\hline XXIV & Understanding organization's performance & 6 & 3 & 12 & 8 & 19 & 3.65 \\
\hline $\mathrm{xXV}$ & Perseverance and hard work & 5 & 6 & 7 & 15 & 15 & 3.60 \\
\hline XXVI & Ability to work in intercultural/international environment & 3 & 9 & 9 & 11 & 16 & 3.58 \\
\hline XXVII & Creativity & 6 & 10 & 4 & 16 & 12 & 3.38 \\
\hline XXVIII & Entrepreneurial spirit, “eye” for new opportunities & 4 & 8 & 16 & 10 & 10 & 3.29 \\
\hline $\mathrm{XIX}$ & Curiosity & 2 & 20 & 5 & 7 & 14 & 3.23 \\
\hline $\mathrm{XXX}$ & Presenting (formal) skills & 8 & 11 & 9 & 5 & 15 & 3.17 \\
\hline XXXI & General knowledge and broad-mind, conceptual thinking & 9 & 8 & 6 & 17 & 8 & 3.15 \\
\hline XXXII & $\begin{array}{l}\text { Process management, ability to work effectively in systems total quality management } \\
\text { (TQM), International Organization for Standardization (ISO), Six Sigma, and so on }\end{array}$ & 5 & 14 & 8 & 14 & 7 & 3.08 \\
\hline XXXIII & Innovation management & 2 & 16 & 20 & 8 & 2 & 2.83 \\
\hline XXXIV & Orientation to customer & 8 & 19 & 8 & 2 & 11 & 2.77 \\
\hline
\end{tabular}


the activity "Assessment of Study Programs at Universities", has reached its recommendations for innovations of educational forms and development of key competencies. The following recommendations were the precious admissions into the educational creation of the study program Construction Technology and Management at the Faculty of Civil Engineering - Technical University of Košice:

\section{A. Continue the application and development of edu-} cational methods that have the potential to develop the key profile competencies of graduates:

- Bachelor's, Master's theses in collaboration with businesses;

- Professional practice or training internship as a part of the study program;

- Internships and practices obtained by students;

- A study stay in a foreign plant of a company;

- Support for start-ups;

- Business game;

- Student competitions announced by companies;

- Individual terminal works in the form of projects;

- Team student projects;

- Mixed teams;

- Actual (business) projects (live projects);

- Workshops and seminars led by students;

- Student company;

- Sports and social clubs;

- Research;

- Surveys/investigations;

- IT-supported learning.

B. Implement new forms of key profile competencies development:

- Engaging students in cooperation of schools and companies in field of research and development;

- Subject/study program as combination of two faculties;

- Training of skills related to employability.

The aim of the project consisted in creation of organization subculture (within study program of a university department) acknowledging right the competencies that have been determined as key profile competencies of graduates. As the individual activities within the innovation fields influence each other, the aim rests upon the creation of a complex system of cooperation between faculty and companies.

\section{Conclusions}

A graduate and his/her ability to be of use in working positions of civil engineering represent the product of the Faculty of Civil Engineering, Technical University of Košice. Graduates of the study program Construction Technology and Management are in for the following working positions involved in the field of construction economy and management:

- Estimating clerk,

- Worker responsible for preparing tender documents,

- Construction project manager,

- Assistant site manager,

- Site manager.

The content and learning methods of professional subjects in the Faculty of Civil Engineering, Technical University of Košice, within the Construction field of study provide a strong theoretical and practical basis, supported by the newest techniques and technologies, for solution of engineering tasks associated with preparation and management of challenging projects of structural and civil engineering. A positive impact on the development of key profile competencies as the most important qualification for successful transition of a graduate to the labor market is expected after application of the priniciples presented in terms of innovations in learning, education content, and forms.

\section{Acknowledgment}

The paper presents the partial results of the project KEGA No. 031TUKE-4/2015 "Use of interdisciplinary knowledge for new programs aimed at improving the investment activities in transport infrastructure projects".

\section{References}

Bitterová, M., \& Hašková, A. (2014). Effectiveness of University Study Programs from Education Economy Point of View (Efektivita študijných programov vysokých škôl z hl'adiska ekonómie vzdelávania). Available at https://vysokoskolacidopraxe.cvtisr. sk/files/bitterova_haskova_efektivita-studijnychprogramov-vs.pdf, cit.12 October, 2016.

Blaško, M. (2016). Quality in the System of Modern Education (Kvalita v systéme modernej výučby). Available at http://web. tuke.sk/kip/download/vuc15.pdf, cit. 26 September, 2016.

Employer and Higher Education Perspectives on Graduates in the Knowledge Society. (2007). Available at https://www.open. ac.uk/cheri/documents/qualitative-report-final-version.pdf, cit. 20 September, 2016.

EUROGRADUATE Consortium: Testing the Feasibility of a European Graduate Study. (2016). Available at https://www.eurashe.eu/ 
library/mission-phe/EUROGRADUATE_feasibility_report.pdf, cit. 25 October, 2016.

European Communities. (2008). The European Qualifications Framework for Lifelong Learning (EQF). European Communities, Belgium. Available at http://www.ecompetences.eu/site/objects/ download/4550_EQFbroch2008en.pdf, cit. 26 September, 2016.

HEGESCO: Higher Education as a Generator of Strategic Competences. (2008). Available at http://eacea.ec.europa.eu/ LLp/project_reports/documents/erasmus/erasmus_2007_ final_reports/eras_emhe_133838.pdf, cit. 10 September, 2016. Hrmo, R., \& Turek, I. (2013). Key Competencies System Design (Návrh systému klúčových kompetencií). Available at https://www.mtf.stuba.sk/docs/internetovy_casopis/2003/2/ hrmo2.pdf, cit. 26 September, 2016.

International Standard Classification of Education ISCED 2011. (2011). Available at http://uis.unesco.org/sites/default/ files/documents/international-standard-classification-ofeducation-isced-2011-en.pdf, cit. 16 September, 2016.

Kleštincová, L. (2011). We Associate Universities with the Labor Market (Spájame vysoké školy s trhom práce), IHP 2011. Available at http://www.ihp.sk/analyzy/IHP-Analyza\%20-\%20 Spajame\%20VS\%20s\%20TP.pdf, cit.12 October, 2016.

Kozlovská, M., \& Spišáková, M. (2013). Construction waste generation across construction project life-cycle. Organization, Technology and Management in Construction, 5(1), pp. 687-695. [ISSN 1847-5450].

Kozlovská, M., Struková, Z., \& Tažiková, A. (2010). Access to construction time objectiveness. Organisation, Technology and Management in Construction: An International Journal, 2(2), pp. 200-206. [ISSN 1847-5450].

Kozlovská, M., Tažiková, A., \& Talian, J. (2015). Integrating economic and managerial skills with an emphasis on needs of labor markets. International Journal for Innovation Education and Research, 3(11), pp. 131-136. [ISSN 2411-3123].
Mesároš, P., Mesárošová, M., \& Mandičák, T. (2014). Research-based education of key competencies of Technical university students. In: SGEM 2014: 14th International Multidisciplinary Scientific Geoconferences: Ecology, Economics, Education and Legislation, Volume 3, Albena, Bulgaria. STEF92 Technology Ltd., Sofia, pp. 679-686.

MŠ SR. (2002). MILÉNIUM: National Program of Education and Learning in Slovak Republic for Following 15 to 20 Years (Národný program výchovy a vzdelávania v Slovenskej republike na najbližších 15 až 20 rokov). Bratislava, IRIS.

MŠMaT ČR. (2001). National Program of Education Development in Czech Republic (Národný program rozvoje vzdělávaní v České republice). Ministry of schools, youth and physical education (Ministerstvo školství, mládeže a tělovýchovy), Praha.

PricewaterhouseCoopers Slovensko, s.r.o. - Centire s.r.o. (2015). Assessment of Effectiveness of Universities Study Programs (Posúdenie efektívnosti študijných programov vysokých škôl), Phase no. 5.

Reflex 2010: The Fourth Report - The Competence of Graduates. (Reflex 2010: zpráva čtvrtá - Kompetence absolventu). (2011). Available at http://www.strediskovzdelavacipolitiky.info/ download/REFLEX2010_Zprava4.pdf, cit. 20 September, 2016.

REFLEX 2013 - Monitoring Reports (REFLEX 2013 - Monitorovací zprávy). (2013). Available at http://www.strediskovzdelavacipolitiky.info/default.asp?page=reflex13MZ, cit. 20 September, 2016.

Tažiková, A., \& Kozlovská, M. (2013). Effect of the construction cost calculations to the sustainable development of buildings. Visnik Nacional'nogo universitetu L'vivska politechnika: Teorija i praktika budivnictva, 756, pp. 298-303. [ISSN 0321-0499].

The Definition and Selection of Key Competencies. Executive Summary. (2005). Available at http://www.oecd.org/ pisa/35070367.pdf, cit. 26 September, 2016. 